\section{Digestion}

Digestion 1998;59(suppl 2):8-10

\section{Alexander L. Gerbes \\ Veit Gülberg \\ Manfred Bilzer}

Department of Medicine II,

Klinikum Grosshadern,

University of Munich, Germany

\title{
Endothelin and Other Mediators in the Pathophysiology of Portal Hypertension
}

\section{Key Words}

Liver cirrhosis - Portal pressure - Hepatic stellate cells ·

Sinusoidal endothelial cells $\cdot$ Kupffer cells

Hyperdynamic circulation as well as increased hepatic resistance contribute to portal hypertension in cirrhosis of the liver [1]. Hyperdynamic circulation with increased cardiac output, heart rate and plasma volume and decreased arterial blood pressure and systemic vasodilatation is pivotal for the hyperdynamic circulation. This has prompted intense research of a number of endogenous neurohumoral mediators with vasodilating properties (NO, natriuretic peptides, glucagon, etc.) [2, 3].

In recent years, however, mechanisms augmenting intrahepatic vascular resistance and thus contributing to portal hypertension have received increasing attention. In this respect, endothelins (ET) are of particular interest [4-8].

ET are a family of 21-amino acid polypeptides with potent vasoactive properties. ET-1 was first isolated in the supernatant of vascular endothelial cells [8] but later synthesis of both circulating isopeptides ET-1 and ET-3 was shown in other organs such as the gastrointestinal tract [9]. ET-1 has mainly vasoconstrictive properties by acting on the $\mathrm{ET}_{\mathrm{A}}$ receptor on smooth muscle cells. ET-1 binds with lower affinity also to the $\mathrm{ET}_{\mathrm{B}}$ receptor on endothelial cells inducing a vasodilatation by the release of NO and prostacyclins. ET-1 exhibits a much higher affinity to the $\mathrm{ET}_{\mathrm{A}}$ receptor than ET-3 whereas the $\mathrm{ET}_{\mathrm{B}}$ receptor exhibits similar affinity for both isopeptides. Vascular response to ET thus depends on the ratio of different receptors which seems to vary in different vascular regions [for reviews, see 5-8]. The role of ET-3, particu- larly regarding portal pressure, has not been fully elucidated yet. Therefore, mainly ET-1 will be covered in the following text.

\section{ET Plasma Concentration and Hepatic Release in Cirrhosis}

In patients with cirrhosis of the liver, elevated arterial and venous plasma concentrations of ET-1 and ET-3 have been described [2,10-16]. Interestingly, there is an increased hepatosplanchnic release of ET in these patients (fig. 1). Release of ET-1 as well as arterial and venous plasma concentrations were found to correlate to the hepatic-venous-pressure gradient $[13,14]$. In the liver of cirrhotic rats, increased concentrations of ET-1 and an increased ET receptor density have been described [17]. Furthermore, release of ET from isolated perfused liver as well as from sinusoidal endothelial cells upon stimulation by TGF- $\beta$ have been observed $[18,19]$. These findings raise the question which cells of the liver synthesize ET and whether this is stimulated in liver damage or cirrhosis.

\section{ET Synthesis in Various Cell Types of the Liver}

Expression of ET-1 in isolated liver cells was detected mainly in sinusoidal endothelial cells and stellate cells

\section{KARGER}

Fax +41613061234

E-Mail karger@karger.ch

www.karger.com
(C)1998 S. Karger AG, Basel

0012-2823/98/0598-0008\$15.00/0
Alexander L. Gerbes

Klinikum Grosshadern, Medizinische Klinik und Poliklinik II

Marchioninistrasse 15, D-81366 Munich (Germany)

Tel. + 490897095 2292, Fax +49 0897095 2392,

E-Mail gerbes@med2.med.uni-muenchen.de 
Fig. 1. ET-1 plasma concentrations in hepatic venous samples (a) and in femoral artery (data not shown) of patients with cirrhosis were significantly $(\mathrm{p}<0.0001)$ higher than in control sujects. In the same patients, hepatosplanchnic release of ET-1 was increased $(\mathrm{p}<0.01)$ compared to controls (b) [Data adapted from 14].

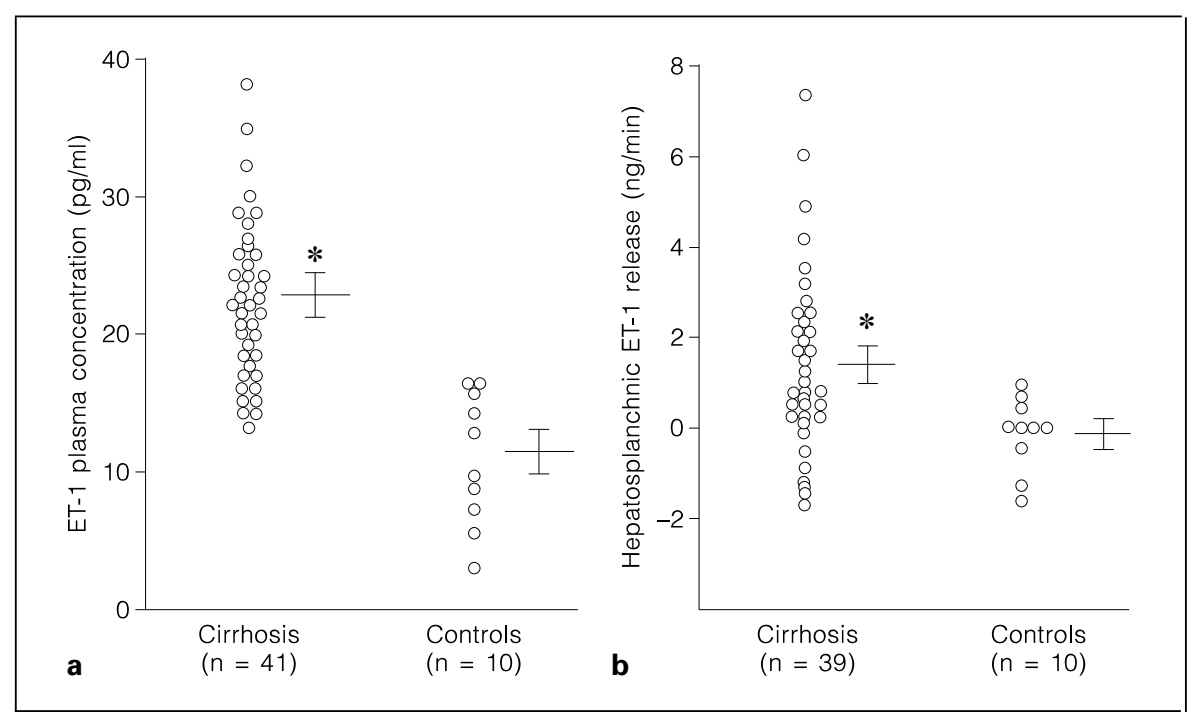

Table 1. Synthesis of and receptors for ET-1 in nonparenchymal and parenchymal cells of the liver

\section{Synthesis}

Endothelial cells $>$ Stellate cells $\gg$ Kupffer cells, Hepatocytes

\section{Receptors}

Stellate cells > Endothelial cells, Kupffer cells, Hepatocytes

and to a lesser extent in Kupffer cells (table 1); following liver injury by bile duct ligation prepro-ET-1 mRNA increased mainly in stellate cells and to a lesser extent in endothelial cells [20]. These data support the finding of ET-1 overexpression in stellate cells and sinusoidal endothelial cells of human cirrhotic liver [21]. Hepatic stellate cells are located in the space of Disse and surround the sinusoidal capillary composed of endothelial cells and Kupffer cells. This anatomic location suggests a role of stellate cells in the regulation of the diameter of liver sinusoids and thus of portal pressure. The data on increased hepatic synthesis of ET in liver damage raise the issue of how ET affects portal pressure and whether there might be endocrine or paracrine effects involved.

\section{ET and Portal Pressure}

ET causes an increase of portal pressure in vivo as well as in isolated perfused liver [22, 23]. In cirrhotic liver, but not in controls, portal pressure decreases upon

Endothelin and Other Mediators in the Pathophysiology of Portal Hypertension administration of an ET receptor antagonist [24]. These data suggest a role of ET in modulating portal pressure particularly in portal hypertension.

\section{ET Effects on Various Cells of the Liver}

ET receptors have been found mainly on stellate cells and sinusoidal endothelial cells but also on Kupffer cells and hepatocytes (table 1) [25-27]. As shown recently, ETinduced decrease of the hepatic microvascular blood flow is predominantly mediated by the contraction of stellate cells [26, 28-30]. Therefore, an autocrine effect of ET appears as an interesting pathomechanism of portal hypertension: in liver damage, increased ET synthesis from stellate cells may induce an increase of portal pressure by contraction of these cells. Furthermore, recent evidence suggests an effect of ET on hepatic microvascular exchange in cirrhosis, possibly by affecting the fenestration of sinusoidal endothelial cells [31]. This might be another mechanism contributing to a decrease of hepatic function in cirrhosis. Finally, the increase of portal pressure upon Kupffer cell stimulation seems to be partly mediated by ET as was recently shown in isolated perfused rat liver [32].

In summary: In conclusion, plasma concentrations of ET are increased in cirrhosis which may be due to increased hepatosplanchnic release. This could reflect increased hepatic synthesis of ET-1, mainly by stellate and sinusoidal endothelial cells. ET increases portal pres- 
sure with sinusoidal constriction by stellate cells playing an important role. Thus, ET modulates portal pressure and is involved in the pathophysiology of portal hypertension.

\section{Acknowledgments}

Supported in part by the Deutsche Forschungsgemeinschaft (DFG Ge576/13-1) and by the Friedrich Baur Stiftung. K. Simon is thanked for the preparation of the manuscript.

\section{References}

1 Gerbes AL, Fischer G, Holl J, Paumgartner G: Therapie der Varizenblutung. Dtsch Med Wochenschr 1996;121:416-423.

2 Bernardi M, Gülberg V, Colantoni A, Trevisani F, Gasbarrini A, Gerbes AL: Plasma endothelin-1 and - 3 in cirrhosis: Relationship with systemic hemodynamics, renal function and neurohumoral systems. J Hepatol 1996;24:161-168.

3 Gerbes AL, Arendt RM, Ritter D, Jüngst D, Zähringer J, Paumgartner G: Plasma atrial natriuretic factor in patients with cirrhosis. N Engl J Med 1985;313:1609-1610.

4 Møller S, Henriksen JH: Endothelins in chronic liver disease. Scand J Clin Invest 1996;56:481490.

5 Yanagisawa M, Masaki T: Molecular biology and biochemistry of the endothelins. Trends Pharmacol Sci 1989;10:374-378.

6 Simonson MS, Dunn MJ: Cellular signaling by peptides of the endothelin gene family. FASEB J 1990;4:2989-3000.

7 Vollmar AM: Endothelins. J Vet Med 1993;39: 481-493.

8 Yanagisawa M, Kurihara H, Kimura S, Tomobe Y, Kobayashi M, Mitsui Y, Yazaki Y, Goto K, Masaki T: A novel potent vasoconstrictor peptide produced by vascular endothelial cells. Nature 1988;332:411-415.

9 Takahashi K, Jones PM, Kanse SM, Lam HC, Spokes RA, Ghatei MA, Bloom SR: Endothelin in the gastrointestinal tract. Gastroenterology 1990;99:1660-1667.

10 Gülberg V, Gerbes AL, Vollmar AM, Paumgartner G: Endothelin-3-like immunoreactivity in plasma of patients with cirrhosis of the liver. Life Sci 1992;51:1165-1169.

11 Moore K, Wendon J, Frazer M, Karani J, Williams R, Badr K: Plasma endothelin immunoreactivity in liver disease and the hepatorenal syndrome. N Engl J Med 1992;327:1774-1778.

12 Gülberg V, Gerbes AL: Relation of endothelins to volume regulating neurohumoral systems in patients with cirrhosis of the liver. Eur J Clin Invest 1995;25:893-898.

13 Gerbes AL, Møller S, Gülberg V, Henriksen JH: Endothelin-1 and -3 plasma concentrations in patients with cirrhosis of the liver - Role of splanchnic and renal passage and liver function. Hepatology 1995;21:735-739.
14 Møller S, Gülberg V, Henriksen JH, Gerbes AL: Endothelin-1 and endothelin-3 in cirrhosis: Relations to systemic and splanchnic haemodynamics. J Hepatol 1995;23:135-144.

15 Gerbes AL: Differentiation of endothelin-1 and endothelin-3 concentrations. Gastroenterology 1993; 105:1591.

16 Rockey D: The cellular pathogenesis of porta hypertension: Stellate cell contractility, endothelin, and nitric oxide. Hepatology 1997;25:2-5.

17 Gandhi CR, Sproat LA, Subbotin VM: Increased hepatic endothelin-1 levels and endothelin receptor density in cirrhotic rats. Life Sci 1996;58:55-62.

18 Bluhm RE, Frazer MG, Vore M, Pinson CW, Badr KF: Endothelins 1 and 3: Potent cholestatic agents secreted and excreted by the liver that interact with cyclosporine. Hepatology 1993;18:961-698.

19 Rieder H, Ramadori G, Meyer KH: Sinusoidal endothelial liver cells in vitro release endothelin - Augmentation by transforming growth factor$\beta$ and Kupffer cell-conditioned media. Klin Wochenschr 1991;69:387-391.

20 Rockey DC, Fouassier L, Chung JJ, Carayon A, Vallée P, Rey C, Housset C: Cellular localization of endothelin-1 and increased production in liver injury - Potential for autocrine and paracrine effects on stellate cells. Hepatology 1998; 27:472-480.

21 Pinzani M, Milani S, De Franco R, Grappone C, Caligiuri A, Gentilini A, Tosti-Guerra C, Maggi M, Failli P, Ruocco C, Gentilini P: Endothelin-1 is overexpressed in human cirrhotic liver and exerts multiple effects on activated hepatic stellate cells. Gastroenterology 1996;110: 534-548.

22 Gandhi CR, Stephenson K, Olson MS: Endothelin, a potent peptide agonist in the liver. J Biol Chem 1990;265:17432-17435.

23 Okumura S, Takei Y, Kawano S, Nagano K, Masuda E, Goto M, Tsuji S, Michida T, Cheng S-S, Kashiwagi T, Fusamoto H, Kamada T, Sato $\mathrm{N}$ : Vasoactive effect of endothelin-1 on rat liver in vivo. Hepatology 1994;19:155-161.
24 Rockey DC, Weisinger RA: Endothelin-induced contractility of stellate cells from normal and cirrhotic rat liver: Implications for regulation of portal pressure and resistance. Hepatology 1996;24:233-240

25 Gondo K, Ueno T, Sakamoto M, Sakisaka S, Sata M, Tanikawa K: The endothelin-1 binding site in rat liver tissue: Light- and electron-microscopic autoradiographic studies. Gastroenterology 1993;104:1745-1749.

26 Housset C, Rockey DC, Bissel DM: Endothelin receptors in rat liver: Lipocytes as a contractile target for endothelin-1. Proc Natl Acad Sci 1993;90:9266-9270.

27 Stephenson K, Harvey SAK, Mustafa SB, Eakes AT, Olson MS: Endothelin association with the cultured rat Kupffer cell: Characterization and regulation. Hepatology 1995;22:896905.

28 Bauer M, Zhang JX, Bauer I, Clemens MG: ET-1-induced alterations of hepatic microcirculation: Sinusoidal and extrasinusoidal sites of action. Am J Physiol 1994;267:G143-G149.

29 Pinzani M, Failli P, Ruocco C, Casini A, Milani S, Baldi E, Giotti A, Gentilini P: Fat-storing cells as liver-specific pericytes: Spatial dynamics of agonist-stimulated intracellular calcium transients. J Clin Invest 1992;90:642-646.

30 Kawada N, Tran-Thi T-A, Klein H, Decker K: The contraction of hepatic stellate (Ito) cells stimulated with vasoactive substances. Eur J Biochem 1993;213:815-823.

31 Reichen J, Gerbes AL, Steiner MJ, Sägesser H, Clozel M: The effect of endothelin and its antagonist bosentan on hemodynamics and microvascular exchange in cirrhotic rat liver. J Hepatol 1998; in press.

32 Bilzer M, Gerbes AL: Prolonged modulation of the hepatic circulation by Kupffer cell-derived oxygen species; in Wisse E, Knook DL, Balabaud C (eds): Cells of the Hepatic Sinusoid. Leiden, The Kupffer Cell Foundation, 1997, vol 6, pp 200-201. 